\title{
Improving usual and dielectric properties of ceramic high voltage insulators
}

\section{(Melhora de propriedades usuais e dielétricas de isolantes cerâmicos de alta voltagem)}

\author{
A. Roula ${ }^{1}$ K. Boudeghdegh ${ }^{1}$, N.Boufafa ${ }^{2}$ \\ ${ }^{1}$ Jijel Univ., LIME, BP 98, Ouled Aissa, Jijel 18000, Algeria.tel/fax:+21334501189 \\ ${ }^{2}$ S.C.S, BP 109, El-Milia 18300, tellfax: +21334456203 \\ amkroula@mail.univ-jijel.dz,scsem@wissal.dz
}

\begin{abstract}
The optimization of the formulation (nature and content of chemical components) and the technical parameters of the shapingup process of ceramic insulators (in replacement of those in glass) are the objectives of this study. The decontamination of $\mathrm{SiO}_{2}$ (solid-liquid extraction of $\mathrm{Fe}_{\mathrm{x}} \mathrm{O}_{\mathrm{y}}$ ) and the increase of both $\mathrm{BaO}$ and $\mathrm{ZrO}_{2}$ amounts (while $\mathrm{Na}_{2} \mathrm{O}$ is partially eliminated) and the firing temperature allowed a significant increase of all the phys-mechanical and insulating properties at the commercial frequency 50-60 Hz. Samples with $15 \mathrm{~mm}$ diameter and $2 \mathrm{~mm}$ thickness and others for mechanical properties were needed. The characterization concerned $\mathrm{Ba}-\mathrm{Zr}\left(\mathrm{Al}_{\mathrm{x}} \mathrm{Si}_{1-\mathrm{x}}\right) \mathrm{O}_{3}$ ceramic samples. By data computing of the test results, a new "computed" formulation (Ba-stabilized and $\mathrm{Zr}$ doped mullite) showed excellent phys-mechanical (density, viscosity, flexural and traction strengths) and insulating properties (transversal resistivity, dielectric strength).
\end{abstract}

Keywords: dielectric ceramic, insulators, mullite, barium oxide, zirconia.

Resumo

A otimização da formulação (natureza e conteúdo dos componentes químicos) e parâmetros técnicos do processo de conformação de isolantes cerâmicos (para substituição dos vítreos) são os objetivos deste estudo. A descontaminação de $\mathrm{SiO}_{2}$ (extração sólidolíquido de $\mathrm{Fe}_{x} \mathrm{O}_{y}$ ) e o aumento das quantidades de $\mathrm{BaO}$ e $\mathrm{ZrO}_{2}$ (enquanto $\mathrm{Na}_{2} \mathrm{O}$ é parcialmente eliminado) e a temperatura de queima permitiram uma significativa melhora nas propriedades físico-mecânicas e isolantes na frequência comercial de $50-60 \mathrm{~Hz}$. Foram necessárias amostras com $15 \mathrm{~mm}$ de diâmetro e $2 \mathrm{~mm}$ de espessura e outras para avaliação de propriedades mecânicas. Foi feita a caracterização de amostras cerâmicas de $\mathrm{Ba}-\mathrm{Zr}\left(\mathrm{Al}_{x} \mathrm{Si}_{1-x}\right) \mathrm{O}_{3}$. Após computação dos resultados dos testes, uma nova formulação "computada" (mullita estabilizada com Ba e dopada com Zr) mostrou excelentes propriedades físico-mecânicas (densidade, viscosidade, resistências a flexão e tração) e isolantes (resistividade transversal, rigidez dielétrica).

Palavras-chave: cerâmica dielétrica, isolantes, mulita, óxido de bário, zircônia.

\section{INTRODUCTION}

Ceramic insulators are widely used in power transmission as well as distribution lines [1-5]. It is also reported that there are many failures of ceramics insulators especially in polluted areas [4, 6-8]. One method to improve the performance of these insulators is optimizing, first, their chemical composition and second, the shaping up and elaboration processes.

In this paper, the mechanical and electrical properties of porcelain ceramic insulator fired and/or sintered at different temperatures have been investigated along with microstructural characterization using scanning electron microscopy (SEM) and $\mathrm{X}$-ray diffraction (XRD) in order to understand the structureproperty relationship of the ceramic insulator.

\section{MATERIALS AND METHODOS}

The simplicity of the production process and its cost were the challenge of this study. To obtain $\mathrm{Ba}-\mathrm{Zr}\left(\mathrm{Al}_{\mathrm{x}}-\mathrm{Si}_{1-\mathrm{x}}\right) \mathrm{O}_{3}$ samples of fired and/or sintered samples with different composition $(\mathrm{x}=1.0,0.2,0.4,0.6,0.8,1.0)$ and according to well known (dielectric and mechanical) characteristics of alkaline, earth-alkaline, silicone and metal oxides and trying to compare different (barium-zirconium)-doped mullite, the following local raw materials were used: high $\mathrm{SiO}_{2}$ sea sand: 0.0098 to $0.0051 \% \mathrm{Fe}_{\mathrm{x}} \mathrm{O}_{\mathrm{y}}$ decontaminated during a solid-liquid diffusion of $\mathrm{Fe}_{\mathrm{x}}^{\mathrm{x}} \mathrm{O}_{\mathrm{y}}^{\mathrm{y}}$ by $[0.25 \mathrm{HF}+$ $0.75 \mathrm{H}_{2} \mathrm{SO}_{4}$ ] in a milling tank; high $\mathrm{Al}_{2} \mathrm{O}_{3}$ clay with $1.25 \% \mathrm{Na}_{2} \mathrm{CO}_{3}+3.18 \% \mathrm{CaCO}_{3}$; barium carbonate with $0.25 \mathrm{BaSiO}_{3}$ : with its large atomic radius $\left(\mathrm{r}_{\mathrm{Ba++}}=13.5 \mathrm{~nm}\right)$, it may contribute to increase the dielectric properties of any silicate formulation while replacing $\mathrm{Na}^{+}$and $\mathrm{K}^{+}$; pure zirconium oxide: with a higher melting point, chemical stability and mechanical resistance; Na-feldspar (albite: $\mathrm{NaAlSi}_{3} \mathrm{O}_{8}$ ): used to decrease the sintering temperature.

The dielectric strength values were determined 
according to CEI 93 normalization on breakdown high voltage apparatus ANM-90. The transversal resistivity values were calculated as the ratio $\rho_{t}=R_{t}(S / e)$, where $\mathrm{R}_{\mathrm{t}}(\Omega)$ is the measured transversal resistance, $\mathrm{S}\left(\mathrm{m}^{2}\right)$ the electrode area, and e (m) the sample thickness. Flexural strength (tree points flexion) values were measured with Netzsch Dynamometer (401/3 model) on parallelepiped samples $\left(150 \times 20 \times 12 \mathrm{~mm}^{3}\right)$.

\section{Optimizing the formulation}

The optimized chemical formulation (amount of each used raw material) must correspond in the same time to the minimal value of the absorption (increase of loss after two hours in boiling water), the maximal value of the flexural strength, the maximal value of the dielectric strength, and the maximal value of the transversal resistivity.

In computing data of simply fired samples, the fourth formulation is the best according to the following values: $\mathrm{SiO}_{2} \sim 38.0 \%, \mathrm{Al}_{2} \mathrm{O}_{3} \sim 50.5 \%, \mathrm{BaO} \sim 7.5 \%,(\mathrm{~K}-\mathrm{Na}) \mathrm{O} \sim$ $3.0 \%$, other $1.0 \%$. This formulation permitted the following properties: Abs. $\sim 15.22 \%, \sigma_{\mathrm{Fl}} \sim 358 \mathrm{Kgf.cm}{ }^{-2}, \rho_{\mathrm{tr}} \sim 5.0$ S.cm, $\mathrm{Rd} \sim 6.2 \mathrm{kV} / \mathrm{mm}$.

As expected, sintering samples containing some (24) $\% \mathrm{ZrO}_{2}$ allowed a substantial increase of the considered properties (see reported values on Table I). This is the result of the increase of the vitreous phase quantity that means some diminution of the absorption values. One precise that before being sintered, the samples were compressed at $20 \mathrm{t} / \mathrm{cm}^{2}$; the $\mathrm{Zr}$-doping of the precipitated mullite (that means the increase of the strength values).

Fresnolite and hyalophane appeared because of a little Ti and $\mathrm{K}$ amounts in the Na-feldspar. Bazerite is the compound with the chemical formula indicating a double silicate: $\mathrm{BaSiO}_{3}-\mathrm{ZrSiO}_{3}$. In this material, mullite seems to be $(\mathrm{Ba}-\mathrm{Na})$ or $(\mathrm{Ba}-\mathrm{K})$ or Ba-doped. The $\mathrm{Zr}$ doping of

Table I - Computed amounts of oxides and properties of studied samples.

[Table I - Teores de óxidos e propriedades das amostras estudadas.]

\begin{tabular}{|c|c|c|c|c|c|c|c|c|c|c|c|c|}
\hline $\mathrm{N}^{\circ}$ & $\begin{array}{c}\text { Fired } \\
1350^{\circ} \mathrm{C}\end{array}$ & $\begin{array}{l}\text { Sintered } \\
1500^{\circ} \mathrm{C}\end{array}$ & $\underset{\%}{\mathrm{Al}_{2} \mathrm{O}_{3}}$ & $\underset{\%}{\mathrm{ZrO}_{2}}$ & $\begin{array}{c}\mathrm{BaO} \\
\%\end{array}$ & $\begin{array}{c}(\mathrm{Na}-\mathrm{K}) \mathrm{O}_{2} \\
\%\end{array}$ & $\underset{\%}{\mathrm{SiO}_{2}}$ & $\begin{array}{l}\text { Rest. } \\
\%\end{array}$ & $\underset{\mathrm{kgf} / \mathrm{cm}^{2}}{\sigma_{\mathrm{R}}}$ & $\begin{array}{l}\mathrm{Abs}_{\mathrm{c}} \\
(\%)\end{array}$ & $\begin{array}{c}\rho . \\
10^{7} \\
\Omega . \mathrm{cm}\end{array}$ & $\underset{\mathrm{kV} / \mathrm{mm}}{\mathrm{R}_{\mathrm{d}}}$ \\
\hline $1^{---}$ & \multirow{9}{*}{+} & \multirow{9}{*}{ - } & 50.0 & \multirow{9}{*}{0.0} & 7.79 & 2.65 & 39.25 & 0.78 & 479.31 & 12.98 & 5.384 & 5.85 \\
\hline $2^{-+}$ & & & 49.94 & & 9.43 & 2.64 & 37.12 & 0.79 & 404.12 & 16.83 & 2.808 & 6.12 \\
\hline $3^{-++}$ & & & 50.22 & & 9.41 & 3.16 & 36.37 & 0.76 & 316.65 & 17.38 & 0.958 & 6.62 \\
\hline 4-- & & & 50.46 & & 7.32 & 3.15 & 38.24 & 0.77 & 358.08 & 15.22 & 4.940 & 6.17 \\
\hline $5^{+++}$ & & & 64.95 & & 9,27 & 2.93 & 22.50 & 0.38 & 256.84 & 20.25 & 2.946 & 6.12 \\
\hline $6^{++-}$ & & & 64.95 & & 9.30 & 2.64 & 24.29 & 0.37 & 202.66 & 16.65 & 2.303 & 5.23 \\
\hline $7^{+-+}$ & & & 64.97 & & 7.22 & 2.95 & 24.47 & 0.32 & 205.04 & 17.69 & 3.708 & 6.08 \\
\hline $8^{+--}$ & & & 65.29 & & 7.24 & 2.66 & 24.35 & 0.54 & 175.45 & 18.37 & 6.595 & 6.58 \\
\hline $\begin{array}{c}9 \\
\text { moy }\end{array}$ & & & 57.63 & & 8.09 & 2.77 & 30.89 & 0.56 & 281.08 & 18.10 & 6.587 & 5.65 \\
\hline 10 & & \multirow[b]{2}{*}{+} & 40.0 & 2.0 & 8.0 & 4.05 & 45.75 & 0.2 & I & 5.39 & 187.6 & 7.87 \\
\hline 11 & & & 49.25 & 4.25 & 5.35 & 3.15 & 38.5 & 0.25 & I & 5.25 & 220.5 & 8.17 \\
\hline \multicolumn{9}{|c|}{ Pure sintered $\mathrm{Al}_{2} \mathrm{O}_{3}[2]$} & 300 & 0.0 & $10^{13}$ & 17 \\
\hline \multicolumn{9}{|c|}{ Pure sintered $\mathrm{ZrO}_{2}[2]$} & 180 & 0.0 & $10^{11}$ & 51 \\
\hline
\end{tabular}

XRD qualitative characterization of sample 11 (see Fig. 1) showed seven peaks corresponding (according to their $\mathrm{I}=\mathrm{f}(\mathbf{2} \theta)$ values) to the following combinations:

\begin{tabular}{ccc}
\hline Compound & Empirical formula & Chemical formula; \% \\
\hline Banalsite & $\mathrm{BaNa}_{2} \mathrm{Al}_{4} \mathrm{SiO}_{16}$ & $23.25 \mathrm{BaO}, 9.40 \mathrm{Na}_{2} \mathrm{O}, 30.92 \mathrm{Al}_{2} \mathrm{O}_{3}, 36.44 \mathrm{SiO}_{2}$ \\
Bazerite & $\mathrm{BaZrSi}_{3} \mathrm{O}_{9}$ & $33.57 \mathrm{BaO}, 26.98 \mathrm{ZrO}_{2}, 39.46 \mathrm{SiO}_{2}$ \\
Walstromite & $\mathrm{BaCa}_{2} \mathrm{Si}_{3} \mathrm{O}_{9}$ & $34.4 \mathrm{BaO}, 25.16 \mathrm{CaO}_{2}, 40.44 \mathrm{SiO}_{2}$ \\
Fresnolite & $\mathrm{Ba}_{2} \mathrm{TiSi}_{2} \mathrm{O}_{8}$ & $60.52 \mathrm{BaO}, 15.76 \mathrm{TiO}_{2}, 23.72 \mathrm{SiO}_{2}$ \\
Hyalophane & $\mathrm{K}_{0.75} \mathrm{Ba}_{0.25} \mathrm{Al}_{1.75} \mathrm{Si}_{2.25} \mathrm{O}_{8}$ & $11.6 \mathrm{~K}_{2} \mathrm{O}, 12.7 \mathrm{BaO}, 29.54 \mathrm{Al}_{2} \mathrm{O}_{3}, 44.76 \mathrm{SiO}_{2}$ \\
Celsian & $\mathrm{BaAl}_{2} \mathrm{SiO}_{8}$ & $40.84 \mathrm{BaO}, 27.16 \mathrm{Al}_{2} \mathrm{O}_{3}, 32.01 \mathrm{SiO}_{2}$ \\
Paracelsian & $\mathrm{BaAl}_{2} \mathrm{SiO}_{8}$ & $40.84 \mathrm{BaO}, 27.16 \mathrm{Al}_{2} \mathrm{O}_{3}, 32.01 \mathrm{SiO}_{2}$ \\
\hline
\end{tabular}




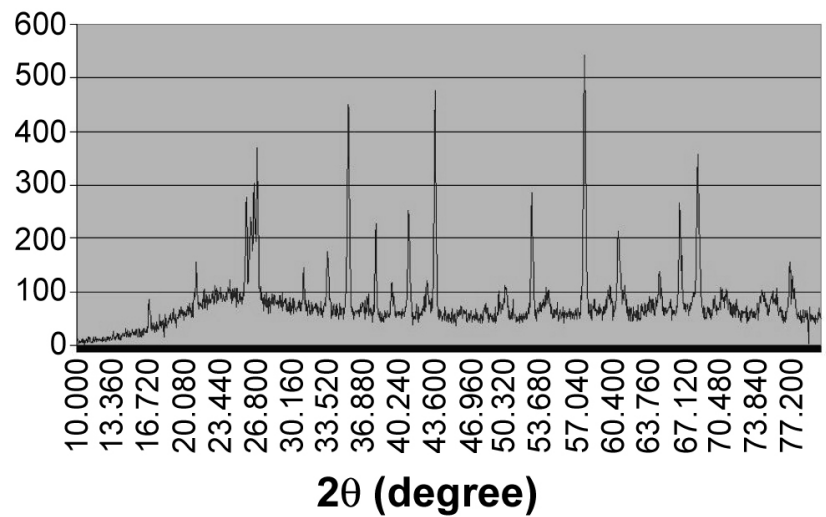

Figure 1: X-ray diffraction pattern of the sample 11. [Figura 1: Difratograma de raios X da amostra 11.]

mullite, that could lead to $\mathrm{Zr}_{\mathrm{x}}\left(\mathrm{SiO}_{3}-\mathrm{Al}_{2} \mathrm{O}_{4}\right)_{\mathrm{y}}$ did not occur because of the complexity of the studied formulation. One must take in account that oxides are the product of the thermal decomposition of raw materials. Better results could be achieved if using pure oxides (e.g: alumina in place of high $\mathrm{Al}_{2} \mathrm{O}_{3}$ clay).

SEM analysis showed (see Fig. 2) a structure with a high heterogeneity level. However, this heterogeneous microstructure is representative of all ceramics: black polyedrical grains are amorphous quartz, while black fibbers are grains of mullite dispersed into this vitreous matrix. Porosity of the material is represented in its black areas.

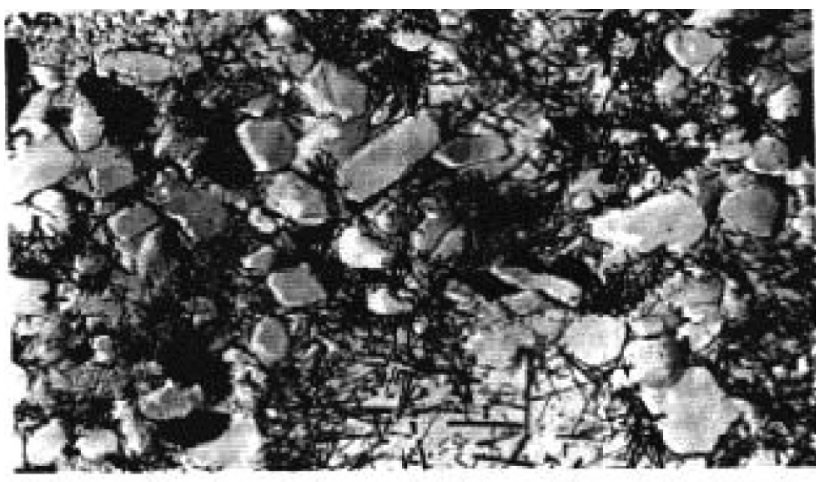

Figure 2: SEM micrograph of the sample. 10 मm [Figura 2: Micrografia MEV da amostra.]

\section{CONCLUSIONS}

One can confirm that the conjugated action of sintering and the addition of zirconia is responsible for the dielectric and mechanical strength improvement. The influence of barium oxide (that partially replaces alkaline oxides) permits a substantial diminution of the material open porosity. This leaded to obtain more amorphous phase in consequence of what we noticed the amelioration of its behavior. An upcoming study of the $\mathrm{Zr}^{2+}$ content influence on the studied properties of sintered ceramics containing $\mathrm{Ba}^{2+}, \mathrm{Na}^{+}$and/or $\mathrm{K}^{+}$oxides must be carried out to envisage a real improvement of their dielectric behavior. Nevertheless, the obtained material is suitable for industrial exploitation because of its high properties (mechanical and dielectric strength).

\section{REFERENCES}

[1] S. Kanazaki, K. Kurihara, S. Iwai, M. Ohashi, H. Tabata, Sintering of mullite silica-ceramics and some properties for insulating substrate material, Yogyo-Kyukai-Shi 95 (1987) 1213-1218.

[2] S. Kanazaki, H. Tabata, Sintering and mechanical properties of stoichiometric mullite, J. Am. Ceram. Soc. 68 (1987) C6-C7 .

[3] M. Horiushi, K. Mizushima, "New mullite ceramic packages and substrates", IEEE Trans. Components, Hybrids and Manufact. Techn. 11, 4 (1988).

[4] D. Dumora, Matériaux isolants céramiques en électrotechnique, Ed. Techn. Ing., Paris (1989) D-2274.

[5] J. F. Macdowell, G. H. Beal, K. Low, Glass-Ceramics for Microelectronic Packaging, Ceram. Trans., Am. Ceram. Soc. Ed., New York, USA (1990) 15.

[6] D. Q. Haiqin, S. H. Guoxin, J. Huang, "Microstructure and properties of aluminous electrical porcelain doped with $\mathrm{BaCO}_{3}$ ", Proc. $3^{\text {rd }}$ Int. Conf. Properties and Applications of Dielectric Materials, Tokyo, Japan (1991).

[7] M. Nemamcha, S. Rouaiguia, A. Belbah, B. Belfarhi, Dielectric properties of aluminosilicates ceramic materials", Proc. IEEE $5^{\text {th }}$ Intern. Conf. Conduction \& Breakdown in Solid Dielectrics (1995).

[8] S. Mej, J. Yang, Aqueous tape casting processing of flow dielectric constant cordierite-based glass-ceramics: selection of binder, J. Eur. Ceram. Soc. 26 (2006) 67-71.

(Rec.08/05/2008, Ac. 18/12/2008) 